\title{
WHY ARE POOR COUNTRIES POOR? *
}

\author{
Daniel Cohen $^{\mathrm{a}}$ and Marcelo Soto ${ }^{\mathrm{b}}$
}

First version: October 2002

This version: December 2003

\begin{abstract}
We attempt to explain why standard explanations of the poverty of nations are unsatisfactory. We first argue that human capital is low in poor countries because its production has increasing returns with respect to life expectancy. We then show that the reason why capital does not flow to poor countries (the Lucas paradox) can readily be explained once market prices rather than PPP prices are used to assess the return to capital. We finally argue that PPP calculations bias downwards the measured TFP of poor countries, which may in part explain their lower productivity. The message of hope is that education can shoot up as life expectancy increases, while physical capital could flow in as the real exchange rate appreciates.
\end{abstract}

JEL classification: F21; J24; O47; P36

\footnotetext{
* The authors would like to thank Paul David, Kenneth Rogoff and Jorge Braga de Macedo for stimulating discussions on the ideas presented here. The views expressed in this paper do not necessarily represent those of the OECD.

${ }^{a}$ Ecole Normale Supérieure and OECD Development Centre. E-mail : dcohen@elias.ens.fr

${ }^{\mathrm{b}}$ Institute for Economic Analysis. E-mail : marcelo.soto@iae.csic.es
} 


\section{Introduction}

Why are poor countries poor? A wide ranging number of answers have been offered to this question. Within the Solow framework, three usual suspects have been rounded up: physical capital, human capital, and total factor productivity. Scarcity of physical capital, first, has been rapidly disregarded as a cause of poverty because no externalities seem to exist and capital mobility worldwide would meet capital shortage (see, among others, Easterly, 1999). Human capital has also been progressively discarded: again, externalities seem to be very low or inexistent (see Heckman and Klenow, 1997, or Krueger and Lindahl, 2001) and the contribution of human capital to growth appears to be too small to explain the gap between rich and poor nations (see, among others, Bils and Klenow, 2000). One could also add that migrant workers earn much more in rich countries than in their home countries, so that human capital cannot be, in isolation, the reason why poor countries are poor. Eventually, only one suspect appears to survive: total factor productivity, which lends itself to the analysis of other kinds of explanatory variables such as institutions or "social infrastructure" as they are called in Hall and Jones (1999).

However, in our view, there is no single factor explaining poverty. Rather than looking for the one big story about the roots of poverty, one needs to explain each of the bits of the development puzzle. In section II we show that while the middle- and low-income countries excluding sub-Saharan Africa have one third of the rich countries' income per head, each of the three items of the production function -physical capital, human capital and total factor productivity- represent on average 70 per cent of the levels attained by rich countries. Similarly, sub-Saharan African countries stand at about one tenth of the rich countries' income level. Yet each of the three items are worth about 50 per cent of the rich countries' levels. This is why we argue that poverty cannot be understood by focusing on just one item but rather we have to address the handicaps in each of these items. In the paper we attempt to explain the origins of these handicaps.

We first address human capital. A Becker/Mincer model would characterize education as an investment that should critically depend on the time horizon on which it is recouped, namely on life expectancy. However, a simple calculation shows that since 1960, every year increase in life expectancy is associated with a rise of more than half a year of schooling in rich countries, but only one third of a year of schooling in poor countries. So, why the reduction of worldwide inequalities in life expectancy has not been channelled into a convergence of educational attainment across the world (the Becker paradox, as we shall call it)? The answer is relatively straightforward: both the theory and the data point to a non-linear relationship between education and life expectancy. In section III we show that in a standard Mincerian approach the decision on schooling is a convex function of life expectancy, which is why the marginal propensity to invest in education rises with life expectancy. In section IV we show empirically that this is indeed the case, with education rising significantly only when life expectancy at the age of 5 is above 50 years. As a result, the poorest countries are only in the early stage of their educational formation.

In section $\mathrm{V}$ we address the Lucas paradox, i.e. the fact that in spite of capital mobility and apparent differences in the rates of return between rich and poor countries, capital does not flow to poor countries. We argue that the paradox arises from a misuse of the Summers-Heston data. 
While these data are certainly very useful for analysing income per head, they cannot be used for gauging the return to physical capital. The proper way to calculate the relative return of capital is to use domestic prices instead of PPP prices. Indeed, the use of PPP prices overestimates the value of marginal productivity of physical capital in poor countries. As we shall see in Section V, the capital output ratios are actually amazingly similar across the world when market prices are used. In other words, there is simply no Lucas paradox when the returns to capital are appropriately measured. By this we do not mean that other factors such as country risk are not important in determining the return to capital. Instead we argue that a proper measure of the return dramatically reduces differences across countries.

Finally, one additional implication that we shall draw from this analysis refers to total factor productivity. We will argue that growth accounting based on Summers-Heston data is likely to bias the measurement of TFP. Indeed, to the extent that the efficient allocation of resources in a poor country is channelled towards the sector which has a relative high market price, this country will not necessarily allocate its resources in the sectors that would be dictated by PPP prices, hence a low TFP level. The inefficiency revealed by TFP may then be exaggerated.

The message of hope that one may then draw from this paper is that a virtuous circle may well be starting sometime soon in poor countries. The progress of life expectancy, if (a big if) it was to be maintained, would increase the investment in education. This would have larger effects on human capital accumulation than it did in the past as non-linearities start to operate. Furthermore, as these countries get richer, the price of non-traded goods would rise. This price increase would raise the profitability of capital, thus eventually attracting more investment from abroad. In the next section we show that factor accumulation is indeed important for economic development, as opposed to the findings of the recent literature.

\section{THE ROLE OF FACTOR ACCUMULATION}

\section{II.1 Income levels}

Let us write aggregate output $\left(Q_{i t}\right)$ of country $i$ at time $t$ as a Cobb-Douglas function of human and physical capital ( $H_{i t}$ and $K_{i t}$ respectively) and total factor productivity $\left(A_{i t}\right)$ :

$$
Q_{i t}=A_{i t} K_{i t}^{\alpha} H_{i t}^{1-\alpha}
$$

This equation is now the received workhouse of growth models. Before analysing the determinants of each of these three items, it is useful to look at the gaps in these items between rich and poor nations implied by the production function. The earlier literature has done this according to different approaches. Our preferred approach amounts to write output per head as the product of three terms: human capital, the ratio of physical to human capital with an exponent of $\alpha$ and total factor productivity (we explore other alternatives below). Setting $\alpha=1 / 3$ and the 
average of high-income countries in each of one these terms equal to one ${ }^{1}$, we obtain the following results:

\section{Table II.1 a Contribution of Human and Physical Capital and Total Factor Productivity to Income}

\begin{tabular}{|c|c|c|c|c|c|}
\hline & & Output per head & Human Capital & $\begin{array}{l}\text { Physical } \\
\text { Capital }\end{array}$ & $\begin{array}{l}\text { Total Factor } \\
\text { Productivity }\end{array}$ \\
\hline \multirow{3}{*}{\multicolumn{2}{|c|}{$\begin{array}{l}\text { Rich countries } \\
\text { Middle- and low-income countries excluding SSA } \\
\text { Sub-Saharan Africa (SSA) }\end{array}$}} & 1 & 1 & 1 & 1 \\
\hline & & 0.35 & 0.65 & 0.69 & 0.75 \\
\hline & & 0.11 & 0.49 & 0.41 & 0.48 \\
\hline Note: & $\begin{array}{l}\text { According to the decomposition } Q / L=A \\
\text { physical capital: each term is divided by the }\end{array}$ & $\begin{array}{l}1 / 3 \\
\text { e of rich countrie }\end{array}$ & $Q / L$ is output $\mathrm{p}$ & $\mathrm{d}, H$ is $\mathrm{h}$ & capital, $K$ is \\
\hline Source: & Cohen and Soto (2001), for Human Capital & ly and Levine (20 & for physical capi & Penn Worl & le 5.6 for out \\
\hline
\end{tabular}

Table II.1a is an amazing illustration of the power of multiplication. While the middle- and low-income countries excluding sub-Saharan Africa stand at about one third of the rich countries' income per head, each of the three items are about 70 per cent (only) of the level of rich countries. But 70 per cent to the power of three is 35 per cent! Similarly, the average income level in subSaharan Africa is only one tenth of rich countries' income level. However each of the three components of the production function is between $40 \%$ and $50 \%$ the levels observed in rich countries. Multiplying small or relatively benign handicaps can yield a dramatic effect on a country's income. This decomposition explains why, in our view, single factor explanations of the poverty of nations are usually found to be unsatisfactory. Neither human nor physical capital alone can explain much. This is also why many authors have argued that differences in total factor productivity are the main source of disparities in income across countries. Table II.1 suggests instead why the "transpiration" strategy of Singapore, which focused on human and physical capital, worked: by fixing two out of three items, a country can go a long way towards solving its development problem. Krugman (1994) referred to the "transpiration" strategy of Singapore echoing Edison's famous remark that it takes more transpiration than inspiration to innovate. Singapore's strategy is indeed one in which most of the growth has appeared to be driven by factor accumulation (in human and physical capital) rather than by total factor productivity (see Young, 1995). The table also gives a hint on why migrant workers do well abroad: their human capital allows them to double their income as they move from middle- and low-income countries (excluding sub-Saharan Africa) to rich countries, and to multiply it by five if they come from subSaharan Africa.

The income decomposition presented above gives a lower role to TFP than most readers of the Hall and Jones (1999) paper would expect. One reason is that our decomposition is slightly different from the one presented by Hall and Jones, who prefer to rewrite the output per worker as a function of the capital-output ratio:

$$
Q_{i t} / L_{i t}=A_{i t}^{1 / 1-\alpha}\left(K_{i t} / Q_{i t}\right)^{\alpha / 1-\alpha}\left(H_{i t} / L_{i t}\right)
$$

\footnotetext{
${ }^{1}$ Table A1 in the appendix shows the countries used in this paper
} 
Table II.1b. Decomposition à la Hall-Jones

\begin{tabular}{llcll}
\hline & $\mathrm{Q} / \mathrm{L}$ & $(\mathrm{K} / \mathrm{Q})^{0.5}$ & $\mathrm{H}$ & $\mathrm{A}^{1.5}$ \\
\hline Rich Countries & 1 & 1 & 1 & 1 \\
Middle- and low-income countries excluding SSA & 0.35 & 0.81 & 0.65 & 0.67 \\
Sub-Saharan Africa (SSA) & 0.11 & 0.60 & 0.49 & 0.35 \\
\hline
\end{tabular}

However, Hall and Jones's decomposition inflates the role of total factor productivity in explaining differences in output across countries (Table II.1b). This is so because they raise the TFP to the power 1.5 and make comparisons with this new definition of TFP. This obviously exacerbates differences in productivity across countries. Hall and Jones argue that decomposing in terms of the capital-output ratio is more relevant than the capital-labour ratio because in the long run the capital-output ratio is constant. As our discussion of the Lucas paradox will show, this is not the case.

At any rate, our decomposition is not widely different from the one used by Hall and Jone. Taking physical and human capital together, factor accumulation has a larger explanatory power than TFP in explaining the poverty of nations. This contradicts the now received idea that factor accumulation could not explain growth. The earlier and most influential papers on this are Benhabib and Spiegel (1994), Bils and Klenow (2000), Klenow and Rodriguez-Clare (1997), and Easterly and Levine (2001). We review critically the arguments given against the role human capital in a companion paper (Cohen-Soto, 2001). There we argue, along Krueger and Lindahl (2001), that measurement errors are too large, which is why increases in education do not seem to be significant in growth regressions.

The tables above presented describe the average differences in each of the three terms of the production function between countries. But averages may mask the underlying causes of poverty. For instance, some developing countries may have a relatively high TFP and others a relatively low one, which would result in an average TFP "not so different" from rich countries'. Therefore, instead of looking at averages, one could compare the richest country with the poorest ones, as Hall and Jones (1999) do. But this is an extreme way to proceed too. An intermediary approach to evaluate the contribution of factor accumulation is through the variance decomposition of the output level, as done by Klenow and Rodriguez-Clare (1997) and Easterly and Levine (2001). Klenow and Rodriguez-Clare make a variance decomposition of the income level across countries similar to:

$$
1=\operatorname{Cov}\left(\log \left(q_{i t}\right) ; \log \left(x_{i t}\right)\right) / \operatorname{Var}\left(\log \left(q_{i t}\right)\right)+\operatorname{Cov}\left(\log \left(q_{i t}\right) ; \log \left(T F P_{i t}\right)\right) / \operatorname{Var}\left(\log \left(q_{i t}\right)\right)
$$

where lowercases represent variables in per worker terms and $x_{i t}$ is an aggregate of total factor accumulation per worker, defined as:

$$
x=k^{1 / 3} h^{2 / 3}
$$


Decomposition (2) is different from the one used by Klenow and Rodriguez-Clare (1997). There the production function is expressed in terms of the capital-output ratio. Such decomposition would be justified if the capital-output ratio were constant. However it is a wellknown fact that, at PPP prices, rich countries tend to have higher capital-output ratios than poor countries. In addition, the estimation of the contribution of the capital-output ratio in total output will be necessarily biased downwards. For these reasons we opt for decomposing income according to the expression (2). As Klenow and Rodriguez-Clare point out, the first term of this expression corresponds to the coefficient obtained in an OLS regression of $\log \left(x_{i t}\right)_{t}$ on $\log \left(q_{i t}\right)$ and a constant and so it can be interpreted as the expected increase in $\log \left(x_{i t}\right)$ given and increase in $\log \left(q_{i t}\right)$. Table II. 2 shows the results of this decomposition. The numbers are qualitatively similar to those of Table II.1. Namely, factor accumulation explains more than $60 \%$ of the variance of the output level. Moreover, this figure has been fairly stable over the period 1960-1990.

Table II.2. Variance decomposition of the income level per worker

\begin{tabular}{lccccc}
\hline & \multicolumn{2}{c}{ Decomposition à la Klenow-Rodriguez } & \multicolumn{2}{c}{ Decomposition à la Easterly-Levine } \\
\hline & Factor Accumulation & TFP & $\begin{array}{c}\text { Factor } \\
\text { Accumulation }\end{array}$ & TFP & Covariance \\
\hline 1960 & 0.64 & 0.36 & 0.48 & 0.20 & 0.32 \\
1970 & 0.63 & 0.37 & 0.47 & 0.20 & 0.33 \\
1980 & 0.65 & 0.35 & 0.49 & 0.19 & 0.32 \\
1990 & 0.62 & 0.38 & 0.44 & 0.19 & 0.37 \\
\hline
\end{tabular}

Easterly and Levine (2001) further decompose (2) in order to account for the covariance between factor accumulation and TFP. This is important because part of the contribution of factor accumulation may be induced by TFP improvements. We consider the covariance in the following expression $^{2}$

$$
\begin{aligned}
1= & \operatorname{Var}\left(\log \left(x_{i t}\right)\right) / \operatorname{Var}\left(\log \left(q_{i t}\right)\right)+\operatorname{Var}\left(\log \left(T F P_{i t}\right)\right) / \operatorname{Var}\left(\log \left(q_{i t}\right)\right) \\
& +2 \times \operatorname{Cov}\left(\log \left(x_{i t}\right) ; \log \left(T F P_{i t}\right)\right) / \operatorname{Var}\left(\log \left(q_{i t}\right)\right)
\end{aligned}
$$

The last three columns of Table II.2 present the main results of the Easterly-Levine decomposition. The variance of factor accumulation alone explains between $40 \%$ and $50 \%$ of the

\footnotetext{
${ }^{2}$ Easterly and Levine assume decreasing returns in $x$, which implies a slightly different formulation for (3). However the hypothesis of decreasing returns is rejected by the data (see Soto, 2002).
} 
output variance. TFP alone explains around $20 \%$ and the remaining $30 \%$ to $40 \%$ is explained by the covariance between factors and TFP. Overall, it is hard to argue from these numbers that TFP is the main determinant of income differences across countries. The role of factors of production is at least as important as TFP's.

\section{II.2 Income growth}

Traditionally the literature has emphasised the differences in output growth rather than differences in the output level. Pritchett (2001) and Easterly and Levine (2001) have argued that discrepancies in the growth rate of human and physical capital are not able to explain discrepancies in the growth rate of output per worker across countries. This may be in part due to measurement error (Krueger and Lindahl, 2001) or collinearity between both types of capital (Soto, 2002). We explore here the significance of the change in capital stocks with a simple regression of output growth on $\Delta x$ and time dummies over the period 1960-1990 (data are for the beginning of each decade). Column 1 of Table II.3 shows the OLS estimate, which results in a coefficient $50 \%$ higher than the value that could have been expected (i.e. one). This is due to the endogeneity of factor accumulation. The $\mathrm{R}^{2}$ is also very high, but it is certainly biased upwards for the same reason. The second column is obtained by using lagged changes of $x$ as instruments. We get a coefficient which perfectly fits the expected value, namely one. Columns 3 and 4 replicate the regressions but constraining the coefficient on $\Delta x$ to one. The $\mathrm{R}^{2}$ is still high, although it falls slightly when the time dummies are dropped (column 4). Globally, these simple regressions show that factor accumulation is a significant determinant of output growth.

Table II.3. Regression of income growth on factor accumulation (1960-1990) (Dependent variable is dlog(output per worker))

\begin{tabular}{|c|c|c|c|c|}
\hline & $\begin{array}{l}(\mathrm{OLS}) \\
(1)\end{array}$ & $\begin{array}{l}(\mathrm{IV})^{*} \\
(2)\end{array}$ & $\begin{array}{c}\text { (OLS; constrained) } \\
\text { (3) }\end{array}$ & $\begin{array}{c}\text { (OLS; constrained) } \\
(4)\end{array}$ \\
\hline Factor Accumulation & $\begin{array}{c}1.57 \\
(0.142)\end{array}$ & $\begin{array}{l}1.02^{\mathrm{a}} \\
(0.536)\end{array}$ & 1.00 & 1.00 \\
\hline $\mathrm{R}^{2}$ & 0.601 & - & 0.553 & 0.439 \\
\hline Observations & 230 & 147 & 230 & 230 \\
\hline
\end{tabular}

However significance does not mean relevance. Easterly and Levine present selected growth accounting results from individual countries in order to measure the share of growth that can be explained by capital growth. Their approach consists in calculating the ratio of capital growth over output growth so that: 


$$
1=\alpha \Delta \log K_{i t} / \Delta \log Q_{i t}+(1-\alpha) \Delta \log L_{i t} / \Delta \log Q_{i t}+\Delta T F P_{i t} / \Delta \log Q_{i t}
$$

where $\alpha$ is the share of physical capital. Note that this expression omits human capital, and so it implicitly assigns any increase in human capital to improvements in total factor productivity. From this exercise the authors draw the conclusion that "detailed growth accounting examinations suggest that TFP growth frequently accounts for the bulk of growth in output for worker". We reproduce their growth accounting results, in per worker terms, in Table II.4.

Table II.4. Growth Accounting per worker (\% of growth explained by Capital Accumulation and by TFP)

\begin{tabular}{lcc}
\hline & $\begin{array}{c}\text { Growth explained by Physical } \\
\text { Capital Accumulation }\end{array}$ & $\begin{array}{c}\text { Growth explained by Human } \\
\text { Capital Accumulation and TFP }\end{array}$ \\
\hline Latin America (1940-1980) (1) & 23 & 77 \\
Latin America (1960-1990) (2) & 63 & 37 \\
East Asia (1966-90) (3) & 71 & 29 \\
\hline Notes: $\quad$ Latin America: Argentina, Brazil, Chile, Mexico and Venezuela. \\
East Asia: Hong-Kong; Singapore, South Korea, Taiwan. \\
Source: Rows (1) and (3): Easterly and Levine (2001) and authors' calculations. Row (2): authors' calculations.
\end{tabular}

During the period 1940-1980, physical capital accumulation explains a relatively modest share of growth, with almost $80 \%$ being explained by TFP and human capital changes. The lack of information on human capital accumulation during that period prevents us from drawing more conclusions about the role of TFP. But we can see that during the period 1960-1990 the share of growth explained by physical capital accumulation increases dramatically. Similarly, Easterly and Levine report a large share of growth explained by capital growth in East Asia. From this table it becomes apparent that capital accumulation explains a large share of growth.

As mentioned before, growth accounting exercises amount to explain average output growth by average factor and TFP growth, which are not necessarily representative of all countries. Besides, another argument raised by Easterly on why factor accumulation cannot be the driver of growth is that factor accumulation is highly serially correlated over time, while growth is not (see Easterly et al., 1993). In itself this empirical observation does not tell us more than the fact that TFP is very volatile on a decade long basis. So TFP may be driving the volatility of growth, but not its secular trend. To see this more clearly we have carried out a variance decomposition of income growth analogous to the one presented in equations (2) and (3). The main results are presented in Table II.5. We have considered three different time frames. With 10-year growth observations, the variance of factor accumulation represents between $25 \%$ and $35 \%$ of the variance of growth (according to the Klenow and Rodriguez-Clare decomposition). But in the full 1960-1990 period the variance of factor accumulation accounts for $44 \%$ of the variance of growth. 
The decomposition of Easterly and Levine results in a lower (but rising with the time horizon) contribution of factor growth. Interestingly the contribution of the covariance between factor growth and TFP growth also increases with the time horizon analysed. However this result tells us nothing about causality. It may be very well the case that human capital is affecting TFP growth.

Table II.5. Variance decomposition of growth per worker

\begin{tabular}{cccccc}
\hline & \multicolumn{2}{c}{ Decomposition a la Klenow-Rodriguez } & \multicolumn{2}{c}{ Decomposition à la Easterly-Levine } \\
\hline & $\begin{array}{c}\text { Factor } \\
\text { accumulation }\end{array}$ & $\begin{array}{c}\text { TFP } \\
\text { growth }\end{array}$ & $\begin{array}{c}\text { Factor } \\
\text { Accumulation }\end{array}$ & $\begin{array}{c}\text { TFP } \\
\text { growth }\end{array}$ & Covariance \\
\hline $1960-1970$ & 0.35 & 0.65 & 0.23 & 0.53 & 0.24 \\
$1970-1980$ & 0.30 & 0.70 & 0.17 & 0.57 & 0.26 \\
$1980-1990$ & 0.25 & 0.75 & 0.16 & 0.66 & 0.18 \\
\hline $1960-1980$ & 0.41 & 0.59 & 0.26 & 0.44 & 0.30 \\
$1970-1990$ & 0.37 & 0.63 & 0.23 & 0.49 & 0.28 \\
\hline $1960-1990$ & 0.44 & 0.56 & 0.28 & 0.40 & 0.32 \\
\hline Source: authors' calculations. & & & & &
\end{tabular}

To conclude, we see that the idea that factor accumulation does not matter for growth is too far fetched. Easterly and Levine put it bluntly: "and if it was factor accumulation, it would remain to be explained why they have not improved more". We address this issue in the next section.

\section{THE BECKER PARADOX}

We first investigate the reason why education has not converged across the world despite the worldwide improvement of life expectancy. Building on Becker and Mincer, the off the shelve model presents education as an investment that critically depends on life expectancy. This would imply that life expectancy and schooling growth together. Table III.1 presents the rough trends of these two variables.

Table III.1. Life expectancy and education

\begin{tabular}{ccc}
$\begin{array}{c}\text { Life Expectancy } \\
\text { at age } 5 \text { (L5) }\end{array}$ & $\begin{array}{c}\text { Average years of } \\
\text { schooling (YS) }\end{array}$ & $\Delta \mathrm{YS} / \Delta \mathrm{L} 5$ \\
\hline
\end{tabular}




\begin{tabular}{lcccc}
\hline & 1960 & 1990 & 1960 & 1990 \\
\hline Rich & 72.3 & 76.9 & 7.6 & 10.5 \\
Middle- and low-income countries excluding SSA & 63.2 & 70.5 & 3.3 & 0.63 \\
Sub-Saharan Africa (SSA) & 54.3 & 60.1 & 0.39 & 1.6 \\
\end{tabular}

We observe that there has been a mild convergence in life expectancy across the world, both in relative and in absolute levels (as we argue below, absolute levels are what matter). Life expectancy in sub-Saharan Africa was on average 18 years lower than in rich countries in 1960; by 1990 it was less than 17. In the rest of the world, the convergence is faster: the discrepancy with rich countries narrowed from 9 years in 1960 to 6.4 years in 1990. This pattern of broad convergence is nevertheless not observed in educational achievement (see Cohen and Soto, 2001). In absolute terms, the discrepancy between rich and poor nations hardly changed over the period 1960-1990 (it actually increased in sub-Saharan Africa). As a result, the ratio of the average increase in years of schooling to the average increase in life expectancy in high-income countries is virtually the double than in the rest of the world.

The question is why that is so. One possible explanation is that the increase in life expectancy in poor countries has not been important enough to trigger investment in human capital. Economists usually portray the relationship between an input and an output as a concave function. But this is not necessarily the case of human capital. According to Mincer, human capital is an exponential function of the number of years of study, implying that the marginal effect of education on human capital, and hence on wealth, is increasing on the former. This has dramatic implications: if life were infinite, one would decide to keep on educating oneself forever. With a finite life, however, some time must be allocated for working in order to reap the benefits of the investment in education. Nevertheless, this insight illustrates why a rising life expectancy may not have the same effect on education in rich and poor countries. We show this more formally in the following model.

Call $T$ the life expectancy, $x$ the number of years spent at school and $X \equiv T-x$ the years spent on the labour market and retirement (we assume that retirement yields the same income as salaries through a pay as you go system). While at school, a person foregoes the wage that could be earned by working full time. But staying a longer time at school yields a higher wage once the person starts working. Assuming that the wage is an exponential function of years of schooling, as supported by dozens of empirical labour studies that followed the pioneering work of Mincer, a worker with $x$ years of schooling gets:

$$
w(x)=w_{0} e^{\delta x}
$$

where $w_{0}$ is the salary obtained without education and $\delta$ is the return to one additional year of schooling. Now assume that, while at school, a student also generates an output worth $b w_{0}$ (housekeeping, value of leisure, pleasure to the parents...) and call $r$ the discount factor, so that $e^{-r t}$ is the present value of a pay-off at time t. A maximization of the lifetime earning implies solving the following problem: 


$$
\underset{x}{\operatorname{Max}}\left\{b \int_{0}^{x} e^{-r t} d t+e^{\delta x} \int_{x}^{T} e^{-r t} d t\right\} w_{0}
$$

The first order condition is:

$$
e^{-(r+\delta) X}=\frac{\delta-r}{\delta} e^{-\delta X}+b \frac{r}{\delta} e^{-\delta T}
$$

This is the expression of an interior solution, which requires that $x>0$ or, equivalently, $X<T$. In the simple case when $\mathrm{b}=0$, this last condition is met if and only if:

$$
\begin{aligned}
& e^{-r T}<\frac{\delta-r}{\delta} \\
& \text { or, } \\
& T>-\frac{1}{r} \log \left(1-\frac{r}{\delta}\right) \equiv T^{m}
\end{aligned}
$$

This means that if life expectancy is not long enough, a person would acquire no education and spend all her life working. If $\mathrm{b}>0$, the threshold value of $\mathrm{T}$ required to investing a positive fraction of the time in education would be lower than $T^{m}$, since the opportunity cost of studying would be relatively low. By contrast, if $b<0$, the minimum value of life expectancy needed to justify some investing in education would be higher than $T^{m}$.

Let us now compute how the working time $X$ varies with $T$. Deriving (3) with respect to $T$, we obtain,

$$
(r+\delta) e^{-(r+\delta) X} \frac{\partial X}{\partial T}=(\delta-r) e^{-\delta X} \frac{\partial X}{\partial T}+b r e^{-\delta T}
$$

Substituting $\mathrm{e}^{-(\mathrm{r}+\delta) \mathrm{X}}$ by (3) and rearranging terms, we get:

$$
\frac{\partial X}{\partial T}=\frac{\delta b e^{-\delta T}}{b(r+\delta) e^{-\delta T}+(\delta-r) e^{-\delta X}}
$$

Then, recalling that $\mathrm{X} \equiv \mathrm{T}-\mathrm{X}$, we have:

$$
\frac{\partial X}{\partial T}=\frac{\delta b}{b(r+\delta)+(\delta-r) e^{\delta x}}
$$


In the particular case when $b=0, \frac{\partial X}{\partial T}=0$ (this can be deduced directly from (3)). This means that any increase in life expectancy is channelled into education, provided that $T$ is sufficiently large. In the general case with $b>0, \frac{\partial X}{\partial T}$ is positive but smaller than 1 . This implies that $x$ increases with $T$, and so $\frac{\partial X}{\partial T}$ is a decreasing function of $T$. Asymptotically, as $T$ tends to infinity, $\frac{\partial X}{\partial T}$ tends towards zero, which means that any marginal increase of $\mathrm{T}$ is fully channelled into education. So we have a non-linear relationship between life expectancy and education such that the marginal propensity to allocate time to education rises towards one. This is represented in Figure 1.

Figure 1. Incremental Schooling to Life Expectancy

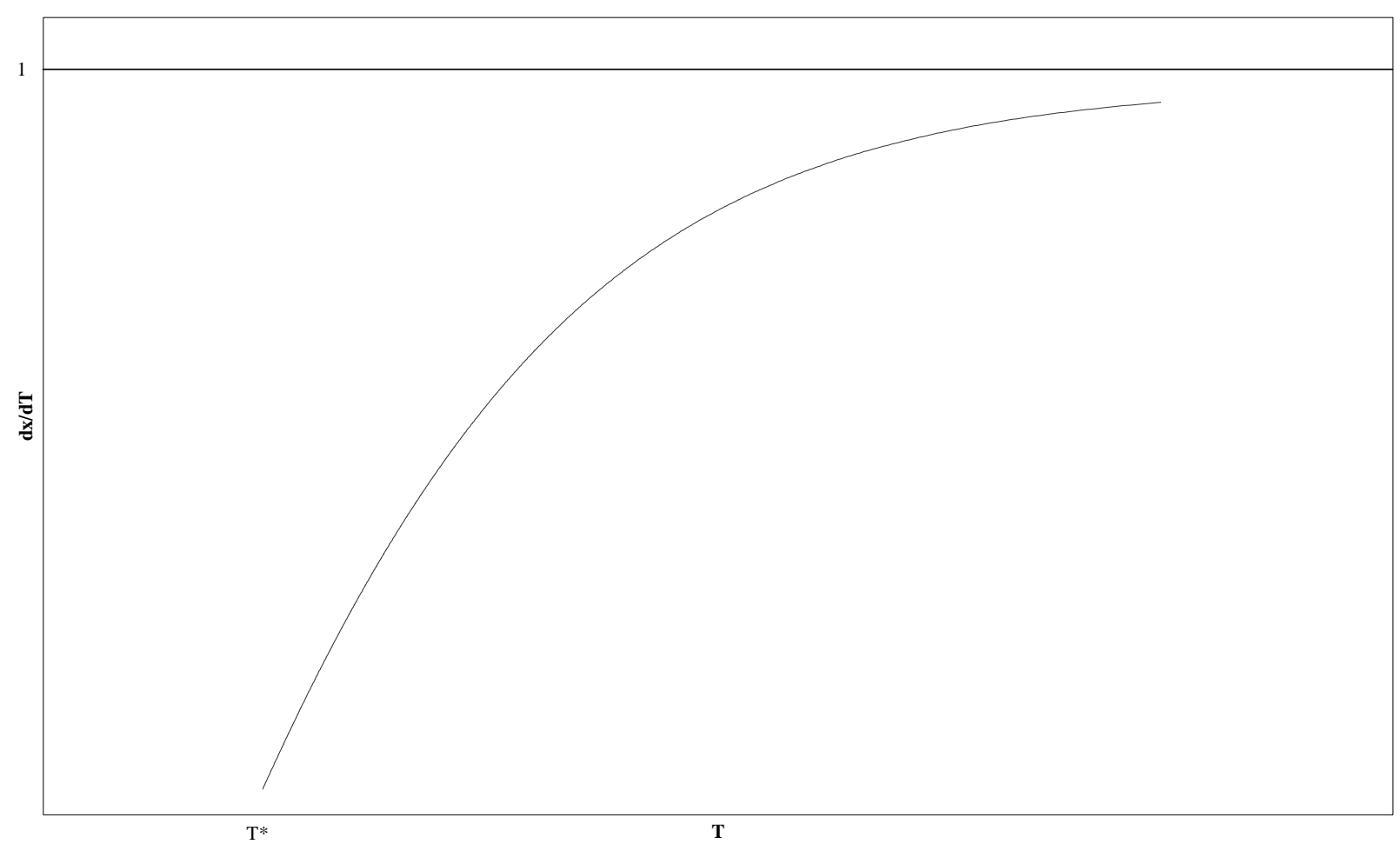

There is a critical value $T^{*}$ below which life is entirely channelled into work life: no schooling takes place below that level. For small values of $T>T^{*}$ the level of education rises mildly with life expectancy. For large values of $T$, virtually any additional increase in life expectancy is assigned to studying. 


\section{Empirical Estimates}

This section analyses the empirical relationship between education and life expectancy. The model of section III predicts a positive relationship between these two variables, with a slope tending towards one. Figure 2 plots life expectancy at the age of 5 in 1990, against the average years of schooling of the population aged 25 to 29 in 2000. These are imperfect measures of the variables implied by the model (the number of years of schooling planned life expectancy at the moment in which the planning is made). We use life expectancy at the age of 5 instead of the more commonly used measure of life expectancy at birth since it reflects better the time horizon faced by a child at the moment she starts the formal education. Similarly, we prefer to use the average years of schooling of the population aged 25 to 29 in 2000 since it gauges better the final educational attainment of the generation under consideration ${ }^{3}$. The figure shows that for low levels of life expectancy the curve is almost flat, but as life expectancy increases the slope becomes steeper. This is exactly what the model predicts.

Figure 2. Life Expectancy and Schooling

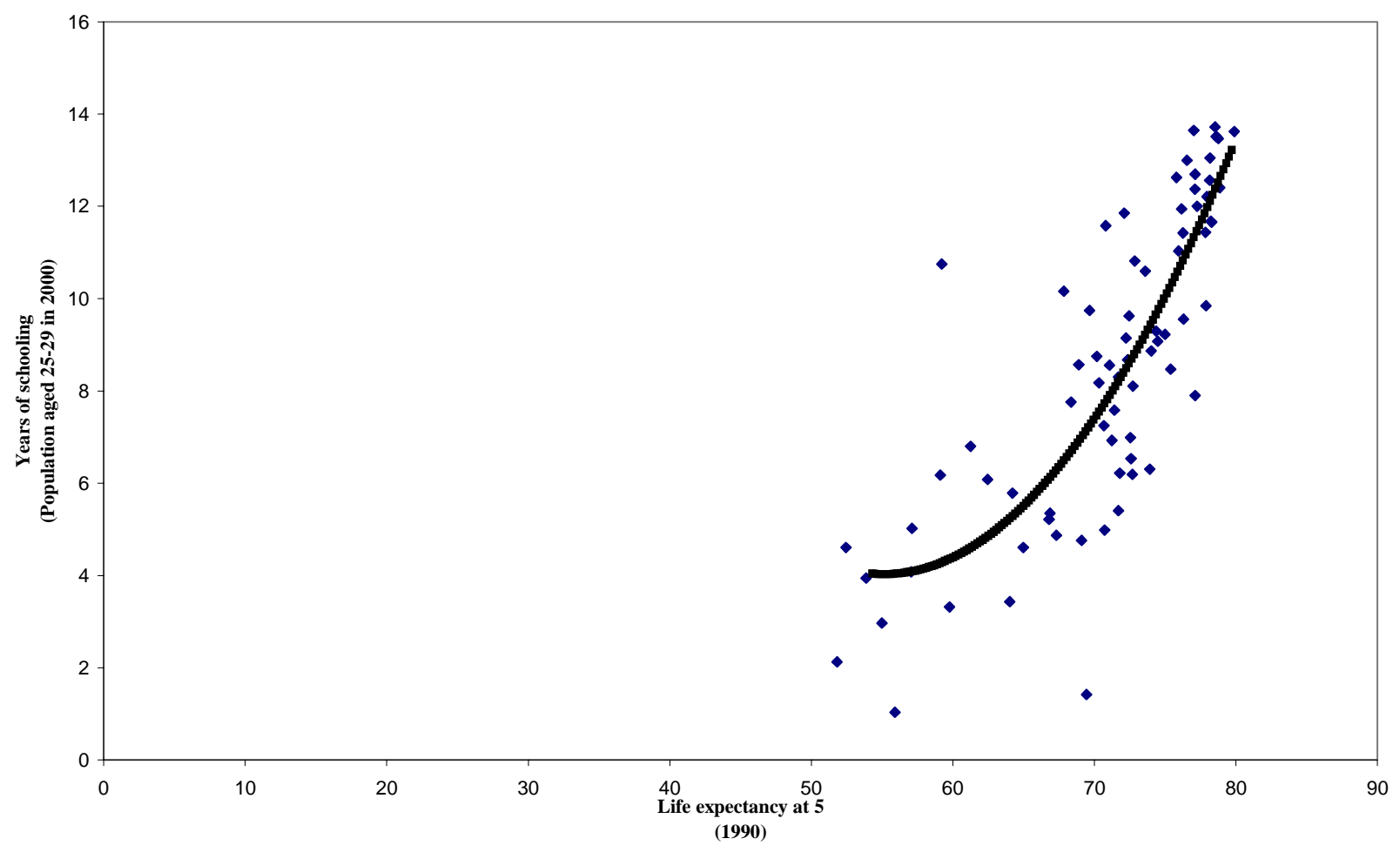

\footnotetext{
${ }^{3}$ It would be even better to use the years of schooling of population aged 25-29 in 2010 but we do not have that information yet!
} 
Next, we proceed to the econometric estimation of the model. The model predicts that schooling is a positive function of life expectancy, with an increasing slope. Table IV.3 presents the results for the estimation of the equation:

$$
\mathrm{YS}_{\mathrm{it}}=\pi_{0}+\pi_{1} \mathrm{~L} 5_{\mathrm{it}-10}+\pi_{2} \mathrm{~L} 5_{\mathrm{it}-10}^{2}+\eta_{\mathrm{i}}+\mathrm{u}_{\mathrm{it}}
$$

where $\mathrm{YS}_{\mathrm{it}}$ is years of schooling of population aged $25-29, \mathrm{~L} 5_{\mathrm{it}}$ is life expectancy at age 5 , $\eta_{\mathrm{i}}$ is a country-specific effect and $u_{i t}$ is a time-varying residual. The equation is estimated for $t=2000$. In most of the regressions, life expectancy is highly significant. The OLS estimates of column 1 suggest that, on average, countries reach a minimum level of education when life expectancy at 5 is 55.3 years. To better illustrate these results, consider the case of Uganda. This country had in 1990 one of the lowest levels of life expectancy at 5 (53.8 years) in the sample. Ten years later YS is estimated at 4.1, whereas the predicted value from column 1 is 3.9. The constrained estimates of column 2 - where the threshold for L5 yielding minimum education levels is fixed at 55 - do not vary substantially.

Table IV.3 Dependent Variable is Years of Schooling of Population 25-29 in 2000

\begin{tabular}{|c|c|c|c|c|}
\hline & $\begin{array}{l}\text { OLS } \\
(1)\end{array}$ & $\begin{array}{l}\text { OLS } \\
(2)\end{array}$ & $\begin{array}{c}\text { GMM } \\
(3)\end{array}$ & $\begin{array}{l}\text { GMM } \\
\text { (4) }\end{array}$ \\
\hline Observations & 74 & 74 & 72 & 72 \\
\hline Constant & $\begin{array}{c}50.3 \\
(18.29)\end{array}$ & $\begin{array}{l}50.49 \\
(3.46)\end{array}$ & $\begin{array}{c}59.95 \\
(44.24)\end{array}$ & $\begin{array}{c}62.28 \\
(12.19)\end{array}$ \\
\hline $\mathrm{L}_{1990}$ & $\begin{array}{l}-1.679 \\
(0.551)\end{array}$ & & $\begin{array}{l}-1.873 \\
(1.323)\end{array}$ & \\
\hline$\left(\mathrm{L} 5_{1990}\right)^{\wedge} 2$ & $\begin{array}{l}1.52 \mathrm{e}-2 \\
(0.51 \mathrm{e}-2)\end{array}$ & & $\begin{array}{l}1.60 \mathrm{e}-2 \\
(0.98 \mathrm{e}-2)\end{array}$ & \\
\hline $\mathrm{L} 5_{1990} \times\left(\mathrm{L} 5_{1990}-\mathrm{C}\right)$ & & $\begin{array}{c}1.53 \mathrm{e}-2 \\
(0.13 \mathrm{e}-2)\end{array}$ & & $\begin{array}{c}1.65 \mathrm{e}-2 \\
(0.38 \mathrm{e}-2)\end{array}$ \\
\hline $\mathrm{R}^{2}$ & 0.672 & 0.672 & 0.647 & 0.647 \\
\hline F-statistic (Prob. Value) & & & $<1 \%$ & $<1 \%$ \\
\hline Sargan (Prob. value) & & & & $95 \%$ \\
\hline
\end{tabular}

Note: Standard errors in parenthesis. Instruments for GMM are: constant, latitude, and lagged change of life 5. C = 110 in column (2) and 117.4 in column 4.

Yet, the OLS estimates are likely to have a positive bias since they do no account for the presence of the country specific effect $\eta_{i}$. Arguably, $\eta_{i}$ is correlated with L $5_{\text {it }}$, hence the source of inconsistency in OLS estimates. Column 3 reports the results obtained by GMM estimation. In addition to a constant, the instruments used are latitude and the 10-year change of L5 $5_{\text {it-10. The }}$ rationale for selecting the latitude of a country as an instrument is that countries with lower latitudes are prone to tropical diseases, an important factor determining life expectancy. At the same time, it is hard to imagine that the latitude may have an impact on years of schooling other than through its effect on life expectancy. So latitude is likely to be a suitable instrument (this is tested later).

The other instrument is $\mathrm{L} 5_{\mathrm{i} 1990}-\mathrm{L} 5_{\mathrm{i} 1980}$. Taking life expectancy in differences removes the country-specific effect and so the source of endogeneity present in this variable disappears. Since the change in life expectancy is correlated with its level, changes are suitable instruments for 
levels. We also tried L5 $5_{11980}$ as an instrument, but its exogeneity was rejected by Sargan tests. This is a clear sign that country-specific effects are present in the dynamics of L5.

Column 3 presents unrestricted estimates of equation (4). As expected, the coefficients are lower than those obtained with OLS, and incidentally, they are not significant. In fact, the GMM estimation reported in column 3 is just identified (we use two instruments for two endogenous regressors), and so the estimation is inefficient. Column 4 presents the constrained version of equation (4), where the threshold life expectancy is set at 54.85 years (this value is obtained from column 3). The constrained estimation reduces the number of regressors and makes possible an efficient estimation. As a result, the coefficient on L5 ${ }_{1990}$ is now highly significant. An F-test for the first stage instrumental variable regression shows that the instruments used are also significant. Finally, a Sargan test shows that the instruments are exogenous.

Using the parameters of column 4, we find that when life expectancy at 5 is worth 72.3 (as in the average of high income countries in 1960), the equation predicts that 45 per cent of life improvement will be channelled into schooling. When life expectancy is worth 63.2 (middle- and low-income countries excluding in 1960) the number falls to 15 per cent. At the levels of life expectancy of sub-Saharan Africa in 1960, virtually no education takes place (the average life expectancy in sub-Saharan Africa has increased since then, which may explain the positive though modest increase in schooling). These numbers understate the actual increase in the $\Delta \mathrm{YS} / \Delta \mathrm{L} 5$ ratio reported in Table III.1, but they are nevertheless consistent with the notion that schooling attainment in countries with lower levels of life expectancy are less responsive to improvements in the later.

\section{THE LUCAS PARADOX}

In order to analyse the Lucas paradox, it should first be emphasised that, in the CobbDouglas production function (1), it does not matter how one interprets $A_{i t}$ (provided, as we postulate, that there are no externalities). Depending on whether technical progress is Harrod, Solow or Hicks Neutral, the interpretation will differ on which remedies are called for in order to improve productivity. Yet, the return to capital accumulation will always be simply driven by the derivative of output with respect to aggregate capital, i.e. as:

$$
r_{i t}=\frac{\partial Q_{i t}}{\partial K_{i t}}=\alpha \frac{Q_{i t}}{K_{i t}}
$$

In the Cobb-Douglas case, as is well known, differences on the rate of return of capital accumulation are simply reflected in differences in average values of the output to capital ratio. In such a framework, the potential for capital mobility is huge as shown in Table V.1 below. 
Table V.1. The Average Productivity of Capital

(rich countries as reference)

\begin{tabular}{lc}
\hline & Physical output to physical capital \\
\hline Rich countries & 1 \\
Middle- and low-income countries excluding SSA & 1.86 \\
Sub-Saharan Africa (SSA) & 3.77 \\
\hline Source: Easterly and Levine (2001), for physical capital; Penn World Table 5.6 for output.
\end{tabular}

We can see that the ratio of output to capital is almost twice as large in middle- and lowincome countries (excluding sub-Saharan Africa) as in rich countries. In the case of sub-Saharan Africa, the corresponding number is almost four times larger. Therefore, if the return to physical capital is so much larger in poor countries, as Table V.1 seems to suggest, why is the capital inflow into poor countries so low? This is the question asked by Lucas, to which a number of papers have been devoted. Lucas himself pointed at the role of externalities, while many other papers have analysed the role of risk of capital expropriation (see Gertler and Rogoff, 1990). The interpretation that we want to suggest comes as follows. Aggregate data in output measured by Summers and Heston data (which usually serves as a basis for tables such as the one reported above) are not appropriate. What matters indeed is to compare the cost of capital to the true (uncorrected for PPP prices) market value of output. In order to see the consequences of this correction, let's set the cost of capital goods equal to one and call $p\left(Q_{i t}\right)$ the market value of the goods produced by country $i$. Assume that in rich countries $p\left(Q_{i t}\right)=1$, but assume that in poor countries $p\left(Q_{i t}\right)<1$. This will be the case for instance if the distance of the periphery to the centre makes the good less valuable either because of the transportation cost or because of the consumers' tastes. In that case the return to investing one unit of capital good is:

$$
r_{i t}=p\left(Q_{i t}\right) \frac{\partial Q_{i t}}{\partial K_{i t}}=\alpha \cdot p\left(Q_{i t}\right) \frac{Q_{i t}}{K_{i t}} .
$$

In other words, in order to assess the return to capital, one needs to weight the physical productivity of capital (such as measured in Table V.1) by the relative price of goods. The inverse of this relative price is shown in Table V.2.

Table V.2. Relative Price of Capital to Output

\begin{tabular}{ll}
\hline Rich countries & 1 \\
Middle- and low-income countries excluding SSA & 1.50 \\
Sub-Saharan Africa (SSA) & 3.32 \\
\hline Source: Penn World Table 5.6.
\end{tabular}

We observe a wide variation of the relative price, which is in part the reflection of the Balassa/Samuelson effect that Summers and Heston intended to correct. In order to assess how much capital can flow into a given country, it is however critical to take account of these price 
differences. This is done below, using the Easterly-Levine (2201) figure for physical capital, and correcting by the relative price of physical capital to output.

\section{Table V.3. Relative Return to Capital}

\begin{tabular}{ll}
\hline Rich countries & 1 \\
Middle- and low-income countries excluding SSA & 0.98 \\
Sub-Saharan Africa (SSA) & 1.10 \\
\hline
\end{tabular}

Note: Output per unit of capital, measured at market prices.

We see here that correcting by the relative price of capital wipes out the discrepancies in the return to capital of Table V.1. Once the correction is made, the return to capital (measured as output per unit of capital, at market prices) is fairly equivalent in the three groups of countries. The ratio is marginally higher in sub-Saharan Africa, but it is well within the measurement error of such type of exercise.

These results should clearly be interpreted with great caution. Many measurement problems remain and the relative returns to capital of Table V.3 are constructed through the macroeconomics of the Cobb-Douglas production function, rather than through direct microeconomic evidence. Direct evidence on the returns to foreign investment in sub-Saharan Africa is reported in a number of papers. The overall picture is itself mixed. In Collier and Gunning (1999), for instance, it is argued that the return on capital in sub-Saharan Africa up to the early 1990s was on average about a third below the average of other emerging countries. Bhattacharya et al. (1996) report instead that returns on FDI are in the range of 24-32 per cent in sub-Saharan Africa, while they are in the 16-18 per cent range for other developing countries. But in a thought provoking paper based on macro data of Tanzania, Devarajan et al. (1999) argue that sub-Saharan Africa's low investment rate is due to its low return to capital. Collier and Patillo (2000) refer to all these points and argue quite convincingly that political risk is a major determinant of low investment in sub-Saharan Africa.

Yet, our interpretation on the apparent differences is not opposed to the existence of political risk. Furthermore, if our intuition is correct, we should find that when the analysis is restricted to the manufacturing sector -which is essentially a tradable sector- we should not observe the kind of capital shortage that we observe in macro PPP data (since the prices of goods in the manufacturing sector are more less the same across countries). Using UNIDO data on manufacturing, we computed capital output ratio across the world. We obtain the following results. 
Table IV.4. Capital- output ratio

in the manufacturing sector

(rich countries as reference)

\begin{tabular}{lc}
\hline & Physical Capital to Physical Output \\
\hline Rich countries & 1 \\
Middle- and low-income countries excluding SSA & 1.37 \\
Sub-Saharan Africa (SSA) & 1.78 \\
\hline
\end{tabular}

Source:UNIDO and author's calculation.

This table shows that in poor countries there is no shortage of capital. In fact, we find that these countries have excess of capital as compared to the average of rich countries. This is exactly the opposite of what we observe with aggregate PPP data and contradicts the Lucas Paradox. Overall, the fact that in the industrial sector we observe excess rather than lack of capital in poor countries supports the view that PPP measures seriously distort the return of capital in aggregate data.

\section{A comment on TFP}

Before closing, it may be interesting to highlight in this section the simple fact that the efficient allocation of resources in a poor country is channelled towards the sector with a high local market price. Summers-Heston (SH) data, which are based on PPP prices, will necessarily point to a lower efficiency in poor countries simply because the allocation of resources in those countries will always appear to be sub-optimal since, to repeat, these are not the true prices under which countries operate. Imagine for instance that the economy consists of two sectors, one traded (say manufacturing) and one which is not traded internationally. Summers and Heston data assign a common relative price to these two sectors, the idea being that a hairdresser performs the same task in New York and in Rio. Yet, if the market price of hairdressing is low, because the country itself is poor, the return to investing physical capital in hairdressing will be low as well: the hairdressing sector will be capital-poor, and so will labour productivity. At SH prices, this will be counted as poor TFP, when it needs not be.

\section{Conclusion}

Because non-traded activities are not valued at the price that they would receive in a rich country, the profitability of capital is low, hence no investment takes place. This keeps the aggregate productivity of workers low. One implication of our analysis is to give support to the "transpiration" model pursued by Singapore (Young, 1995, and Krugman, 1994). Countries can benefit more than is usually thought by simply raising human and physical capital stocks. Indeed, despite the huge differences in income across countries, a typical firm in a developing country does not perform so badly compared to a firm in a rich country: it is not too far from the frontier of total productivity, nor is it too far from the level of human and physical capital either observed 
in rich countries. So, small progress in each of these items may lead the typical developing country substantially closer to the income level of rich countries. The message of hope is that increases in life expectancy may trigger economic development by pulling human capital accumulation and thus increasing the productivity of physical capital. The increased productivity could eventually attract investment. By contrast, countries suffering from a deterioration of health conditions will very likely, if not already, suffer from a serious decline of their income levels as a consequence of the fall in human and physical accumulation. 


\section{Appendix: countries used}

Table Al

\begin{tabular}{|c|c|c|}
\hline Rich countries & $\begin{array}{l}\text { Low- and middle-income countries } \\
\text { excluding SSA }\end{array}$ & Sub-Saharan Africa (SSA) \\
\hline Australia & Algeria & Benin \\
\hline Austria & Argentina & Burkina Faso \\
\hline Belgium & Bangladesh & Burundi \\
\hline Canada & Bolivia & Cameroon \\
\hline Cyprus & Brazil & Central African Republic \\
\hline Denmark & Chile & Gabon \\
\hline Finland & China & Ghana \\
\hline France & Colombia & Cote d'Ivoire \\
\hline Greece & Costa Rica & Kenya \\
\hline Ireland & Dominican Republic & Madagascar \\
\hline Italy & Ecuador & Malawi \\
\hline Japan & Egypt, Arab Rep. & Mali \\
\hline Netherlands & El Salvador & Mauritius \\
\hline New Zealand & Fiji & Nigeria \\
\hline Norway & Guatemala & Senegal \\
\hline Portugal & Guyana & Sierra Leone \\
\hline Singapore & Honduras & South Africa \\
\hline Spain & Hungary & Uganda \\
\hline Sweden & India & Zambia \\
\hline Switzerland & Indonesia & Zimbabwe \\
\hline United Kingdom & Iran, Islamic Rep. & \\
\hline \multirow[t]{18}{*}{ United States } & Jamaica & \\
\hline & Jordan & \\
\hline & Korea, Rep. & \\
\hline & Malaysia & \\
\hline & Mexico & \\
\hline & Morocco & \\
\hline & Nicaragua & \\
\hline & Panama & \\
\hline & Paraguay & \\
\hline & Peru & \\
\hline & Philippines & \\
\hline & Syrian Arab Republic & \\
\hline & Thailand & \\
\hline & Trinidad and Tobago & \\
\hline & Tunisia & \\
\hline & Turkey & \\
\hline & Uruguay & \\
\hline & Venezuela, RB & \\
\hline
\end{tabular}




\section{Bibliography}

Acemoglu, D. and F. ZiLiBotti (2001), "Productivity Differences", The Quarterly Journal of Economics, May, Vol. 116, pp. 563-606.

Bhattacharya, A, P. Montiel and S. Sharam (1996), "Private Capital Flows to Sub-Saharan Africa", Research Department, International Monetary Fund, Washington, D.C.

BILS, M. and P. KLENOW (2000), “Does Schooling Cause Growth?”, American Economic Review, (90)5, pp. 1160-83.

CoE, D., E. HeLPMAN and A. HofFMAISTER (1997), "North-South R\&D Spillovers”, Economic Journal, 107(440).

CoHEn, D. (2002), "Fear of Globalization: The Human Capital Nexus", Annual World Bank Conference on Development Economics, pp. 69-93.

CoHen, D. and M. Soto (2001), "Growth and Human Capital: Good Data, Good Results”, CEPR Working Paper, No. 3100, Centre for Economic Policy Research, London.

Collier, P. and J.W. GunNING (1999) «Explaining African Economic Performance» Journal of Economic Literature, 37 (1), 64-111.

Collier, P. and C. PATillo (eds.) (2000), Investment and Risk in Africa, Macmillan Press, London.

Devarajan, S., W. Easterly and H. Pack (1999), "Is Investment in Africa Too High or Too Low? Macro and Micro Evidence”, World Bank, mimeo, Washington, D.C.

EASTERLy, W. (1999), “The Ghost of Financing Gap: Testing the Growth Model Used in the International Financial Institutions", Journal of Development Economics, 60(2), December, pp. 423-38.

Easterly, W., M. Kremer, L. Pritchett and L. Summers (1993), "Good Policies or Good Luck? Country Performances and Temporary Shocks", Journal of Monetary Economics, 32(3), pp. 459-83.

EASTERLy, W. and R. LEVINE (2001), "It's Not Factor Accumulation: Stylized Facts and Growth Models”, The World Bank Economic Review, 15(2), pp. 177-219.

Gertler, M. and K. Rogoff (1990), "North South Lending and Endogenous Domestic Policies Inefficiencies", Journal of Monetary Economics, 26, pp. 245-266.

Hall, R.E. and C.I. Jones (1999), "Why Do Some Countries Produce So Much More Output Per Worker Than Others?", The Quarterly Journal of Economics, 114(1), pp. 83-116.

HeCKMAN, J. and P. KLENOW (1997), “Human Capital Policy”, mimeo, University of Chicago.

Klenow, P. and A. RodrigueZ-Clare (1997), “The Neo-Classical Revival in Growth Economics: Has it Gone Too Far?”, NBER Macroeconomics Annual, National Bureau of Economic Research, Cambridge, Massachusetts.

Krugman, P. (1994), “The Myth of Asia's Miracle”, Foreign Affairs, 73(6), Nov.-Dec., pp. 62-78.

Krueger, A. and M. Lindahl (2001), "Education for Growth: Why and For Whom", Journal of Economic Literature 39(4), 1101-1136.

LUCAS, R. (1988), “On the Mechanics of Economic Development”, Journal of Monetary Economics, 22, pp. 3-42.

MINCER, J. (1974), Schooling, Experience, and Earnings, Columbia University Press, New York.

Soto, M. (2002), “Rediscovering Education”, TP 202, OECD Development Centre, Paris.

Young, A. (1995), "The Tyranny of Numbers: Confronting the Statistical Realities of the East Asian Growth Experience", The Quarterly Journal of Economics, 110(3), pp. 641-680. 
